\author{
Maryna Yunina \\ Ph.D. \\ (the Dnipropetrovsk State University \\ of Internal Affairs)
}

DOI: $10.31733 / 2078-3566-2018-2-147-150$

\title{
РОЛЬ ОСОБИСТОГО ЗАКОНУ ТА НАЦІОНАЛЬНОСТІ У ВИЗНАЧЕННІ ПРАВОЗДАТНОСТІ ЮРИДИЧНИХ ОСІБ У МІЖНАРОДНОМУ ПРИВАТНОМУ ПРАВІ
}

\begin{abstract}
ЮНіНа М. РОЛЬ ОСОБИСТОГО ЗАКОНУ ТА НАЦІОНАЛЬНОСТІ У ВИЗНАЧЕННІ ПРАВОЗДАТНОСТІ ЮРИДИЧНИХ ОСІБ У МІЖНАРОДНОМУ ПРИВАТНОМУ ПРАВІ. Досліджено роль особистого закону та національності у визначенні правоздатності і дієздатності іноземних юридичних осіб у міжнародному приватному праві. Автором охарактеризовано також критерії визначення національності іноземних юридичних осіб та сучасні тенденції у визначенні національності юридичних осіб. При цьому зроблено висновок про те, що поняття особистого закону і національності взаємозалежні та взаємообумовлені: національність юридичної особи визначає іiі особистий закон, а зміст особистого закону залежить від того, яку національність має юридична особа. Особистий закон юридичної особи відповідає на питання, чи є дане утворення юридичною особою, яким є обсяг його правоздатності, а національність юридичної особи дозволяє кожній державі визначити державну приналежність юридичної особи, що є підставою встановлення певного правового режиму діяльності цього суб'єкта у певній країні.

Ключові слова: іноземна юридична особа, особистий закон, начіональність юридичної особи, ичивільна правоздатність юридичної особи, ичвільна дієздатність юридичної особи.
\end{abstract}

Formulation of the problem. In today's socio-economic conditions, the processes of internationalization and globalization of social life, which have not crossed the activities of legal entities, which are not limited to the borders of one country, are becoming increasingly popular. More and more legal entities are becoming transnational or attracting foreign capital to carry out their activities. The indicated processes make a legal person one of the main subjects of international private law relations, the definition of which legal status on the basis of analysis of legal categories of nationality and personal law is one of the topical issues of modern international private law. Particular attention should be paid to the recognition of the legal capacity of foreign legal entities by the country on the territory of which such a legal entity intends to carry out or carries out its activities, as well as the determination of the legal status of legal persons operating outside the country of their nationality.

Analysis of publications that initiated the solution to this problem. In the study of the nationality and personal law of legal entities in the international privat law, as well as their role in determining the legal capacity of a legal entity paid much attention to authors such as MM Boguslavsky, E.O. Kharitonov, N.O. Saniahmetova, R.O. Halfina, GS Fediniak, SM Heda, R.V. Chernolutsky and others.

The purpose of this article is to study the role of personal law and nationality in determining the legal capacity of legal entities in private international law.

Presenting main material. Legislation of the majority of countries of the world proceeds from the fact that the concept of legal capacity and legal capacity of legal entities coincides in content, since these two concepts almost always exist inseparably, that the presence of legal capacity in a legal entity means at the same time that it also possesses capacity [14, p. 122].

In modern science of civil law, there is no consensus on the nature of the legal capacity of a legal entity. Thus, according to the general rule established by the Civil Code of Ukraine, a legal entity has a general legal capacity. Art. 91 of the Civil Code of Ukraine determines that a legal entity is capable of having the same civil rights and obligations as an individual, other than those which by their nature may belong only to a person. Also, the principle of general legal capacity is enshrined in the law of France on associations, whose activities are aimed at profit, and in the legislation of England on legal entities created by a special act of the king [16, p. 77-78]. That is, the general legal capacity gives the right to a legal entity to acquire any civil

(C) Yunina M., 2018 
rights and carry civil duties, except for those for which the prerequisite is the inherent qualities of a person. It is believed that the legalization of general legal capacity was initiated by the First Council Directive (March 9, 1968), which provided for the responsibility of the campaign to third parties and for such actions that go beyond the objectives of the charter [3, p. 88].

However, in some countries, legislation recognizes legal entities as having special legal capacity, that is, entitles a legal entity to acquire rights and obligations in accordance with the purposes specified in the statute, contract or legal act. This type of legal capacity is enshrined in the laws of Japan, Italy and some other states [13]. In the United States the ultra vires principle is formally considered (agreements beyond the scope of the legal entities are considered invalid), however, the legal capacity of legal entities is actually legalized [1, p. 481-493].

Taking into account the differences in the legal capacity of national legal entities and foreign legal entities operating in the territory of Ukraine, which is due to the provision of the foreign legal entity not only the rights and obligations enshrined in the law of Ukraine, but also those rights and obligations, which are granted to a foreign legal entity by the law of the relevant foreign state and the norms of international agreements, in our opinion, should be recognized by foreign legal entities for the availability of special legal capacity. The term "special" in this case means a complex of exceptions and restrictions that distinguish the legal regime of the activities of foreign legal entities from the regime of Ukrainian legal entities [17, p. 16].

In order for a foreign legal entity to have the opportunity to carry out business activities in other countries, it is necessary to resolve the issue of recognizing the legal capacity of such a foreign legal entity and allowing it to carry out business activities in the territory of the state, as well as the conditions for such activity. Thus, the admission of foreign legal entities to the conduct of economic or other activity on the territory of Ukraine and the legal status of such persons are regulated by the legislation of Ukraine, that is, the law of place of business is applied. However, a legal entity can not have more rights abroad than it would have under a personal law.

The definition of the legal capacity of foreign legal entities and the companies formed in their participation in Ukraine is based on the conflict laws of Ukraine and international agreements. In accordance with the Law of Ukraine "On Private International Law" the legal capacity of foreign legal entities on the territory of Ukraine is determined by the personal law (charter) of a legal entity (Article 26 of the Law).

In order to clarify the law and order, which acquires the meaning of a personal law of a legal person and on the basis of which its legal status is determined, it is necessary to identify this person as a foreign or national entity, that is, to determine the nationality of this legal entity.

In the science of international private law, under the nationality of a legal entity, such a property that determines the legal relationship between a legal entity and a state, its state affiliation, which submits this legal entity to the relevant order and puts it under the protection of a particular state, will acquire it. The indicated means means that the legal entity in all spheres of creation, operation and termination of activity is subject to the rules adopted in the respective state. From this point of view, "nationality" is characterized as the legal person's affiliation with the legal order established in a state, the interconnection of its rules in force in that state that govern the conditions for the emergence, activity and termination of the existence of legal entities. The national rule-of-law of the state acquires the character of the personal law of a legal entity, which defines its civil law, becomes its personal law.

Analyzing legal literature, we can conclude that to date, private international law has not produced a single universally accepted concept of determining the nationality of legal entities. Several criteria have been developed in the science of international private law, on the basis of which the nationality of a legal entity is determined. Such criteria are, for example, the criterion for the main activity, the criteria for the location of the bodies of management of a legal entity, the criterion of the place of establishment, and others. In accordance with these principles, private international law distinguishes doctrine of residence (the law of the place of residence of the governing bodies of a legal entity), the doctrine of the "center of operation" (place of business), the doctrine of incorporation (the law of the place of establishment of a legal entity) [4, p. 215].

At present, in the European states two main criteria for determining the legal status of a legal entity - the criterion of incorporation (assimilation) and the criterion of residence (place of residence) are used.

The residence criterion is used in a sufficiently large number of countries, for example 
in France, Germany, Belgium, Poland and other countries of continental law. According to this criterion, a personal law (nationality) of a legal entity recognizes the law of the location of its administrative center.

Despite the fact that most EU Member States use cetera of residence in practice, some countries, such as Great Britain, Denmark, Ireland, Czech Republic, the Netherlands, adhere to the criterion of incorporation. The main content of this criterion is that the legal entity has the nationality of the country in accordance with the law of which it is based.

The Law of Ukraine "On Private International Law" to determine the legal status of a legal entity and to determine the extent of its civil capacity, also applies the criterion of incorporation. According to Article 25 of the said Law, the law of a legal entity is the law of the country of the legal entity. The legal entity is recognized as the state in which the legal entity is registered or created otherwise in accordance with the law of that State [10].

The criterion of incorporation is also used in other normative acts of modern Ukrainian legislation. For example, in Art. 1 Law of Ukraine "On the regime of foreign investment" stipulates that investors who carry out investment activities in the territory of Ukraine may be legal entities established in accordance with the legislation of a different law than the legislation of Ukraine.

One can agree with the idea that the advantages of the incorporation criterion are its clarity and ease of installation, since the administrative act of registration of a legal entity is easily identified in time and space; without the consent of the state, under the laws of which a legal entity is registered, it can not change its nationality; if the activity of a legal entity is recognized as undesirable for the State of incorporation, it may eliminate this legal entity not only in its own country, but also abroad [9, p. 208].

The undoubted advantage of the incorporation criterion is also that if a legal person has already been created in accordance with the legislation of the country of incorporation and if its foundation was not invalid, then such a legal entity can transfer the seat of its bodies from one country to another without losing primary right-subjectivity.

Despite these advantages, this criterion has a number of shortcomings, which may include the absence of a link between the law of the place of establishment of a legal entity and the law of its place of business, resulting in the provision of unlimited opportunities for founders for numerous manipulations when creating a legal entity. The choice made by the company's founders in favor of the law of the country where the company was incorporated may violate the interests of the country in which the company carries out business operations, as well as the interests of creditors located in this country [7, p. 217].

However, analyzing the legal literature, we can conclude that under present conditions none of the existing conflict criteria for determining the nationality of legal entities can not be favored. Each of them highlights one side of the problem: the criteria for determining the nationality of legal entities by the nationality of individuals included in it - the relationship of a legal entity with individuals, it is directly interested in it; the criterion of incorporation - the connection with the law-order, generating a legal entity; accommodation criterion - connection with property complex, guarantee of interests of creditors. However, the application of each of these criteria alone is not sufficient to determine the legal status of legal entities in all possible cases [6, p. 34-35].

Legislation and law enforcement practices of many states increasingly abandon the "absolute" character of classical conflict criteria, replacing them with mixed criteria. The doctrinal is justified by the importance of taking into account the various aspects of the activities of legal entities, for the purpose for which their nationality is determined. At the same time, two or more criteria for determining nationality are often used simultaneously, using one as the main one, and the other as an additional one.

All these processes confirm the legal opinion shown in the legal literature that the stateof-the-art state of private international law provides grounds for the gradual decline of the role of numerous classical collision bindings and the replacement by a small number of basic principles to determine the law to be applied to legal relationships $[5, \mathrm{p}$. 15]. These principles include the current principle of finding the closest connection of the legal relationship with a specific law and order, finding the most favorable law and order, taking into account the imperative rules of the court of the country.

Conclusions. Thus, the notion of personal law and nationality is interdependent and interdependent: the nationality of a legal entity is determined by its personal constitution, and the content of the personal law depends on the nationality of the legal person. The personal law of 
a legal entity answers the question of whether this formation is a legal person, which is the extent of his capacity. Nationality of a legal entity allows each state to determine the state affiliation of a legal entity, which is the basis for establishing a certain legal regime for the activity of this entity in a particular country, the limits of its subordination to legislative and administrative acts of the state to which this legal entity belongs, and the state in which it carries out its activity.

\section{References}

1. Бернхем В. Вступ до права та правової системи США. Київ, 1999. 560 с.

2. Богуславский М.М. Международное частное право: учебник. Москва: Юрист, 2002. $408 \mathrm{c}$.

3. Васильев Е.А., Зайцева В.В., Костин А.А. Гражданское и торговое право капиталистических государств. Москва: Междунар. отношения, 1993. 560 с. $686 \mathrm{c}$.

4. Звеков В.П. Международное частное право: курс лекций. Москва: «Инфра-М», 1999.

5. Кабатова Е.В. Изменение роли коллизионного метода в международном частном праве. Международное частное право: Современная практика / под ред. М.М. Богуславского и А.Г. Светланова. Москва: ТОН-Остожье, 2000.

6. Корецкий В.М. Проблемы международного частного права в договорах, заключенных советскими республиками с иностранными государствами. Избранные труды. Кн. 1. Киев, 1989. $240 \mathrm{c}$.

7. Кох Х., Магнус У., Винклер фон Моренфельс П. Международное частное и сравнительное правоведение. Москва: Международные отношения, 2001. 400 с.

8. Міжнародне приватне право: навч. посібник / за ред. В.М. Гайворонського, В.П. Жушмана. Київ: Юрінком Інтер, 2005. 366 с.

9. Пєтров В.В. Особливості цивільної правосуб'єктності юридичних осіб: окремі аспекти. Актуальні проблеми держави та права. 2008. С. 205-208. URL: http://www.apdp.in.ua/v43/37.pdf (дата звернення: 21.05.2018).

10. Про міжнародне приватне право: закон України від 23.06.2005 р. Відомості Верховної Ради України. 2005. № 32. Ст. 422.

11. Суворов Л.Л. Проблема отделения личного статута юридического лица от его государственной принадлежности в современном международном частном праве. Журнал международного частного права. 1995. № 3. С. 3-12.

12. Федіняк Г.С. Межі здійснення правосуб'єктності юридичними особами України за кордоном (приватно-правовий аспект). Право Украӥни. 2003. № 12. С. 126-129.

13. Хєда С.М. Поняття та обсяг цивільної правосуб'єктності іноземних юридичних осіб за законодавством України. Вісник Хмельнииького інституту регіонального управління та права. 2002. № 2. C. 48-50. URL: http://nbuv.gov.ua/UJRN/Unzap_2002_2_16 (дата звернення: 21.05.2018).

14. Цивільне право України: підручник/ за ред. Є.О. Харитонова, Н.О. Саніахметової. Київ: Істина, 2003. 560 с.

15. Чорнолуцький Р.В. Проблеми правосуб'єктності осіб у колізі ному праві України: автореф. дис. на здобуття наук. ступеня канд. юрид. наук: 12.00.03. Одеса, 2006. 20 с.

16. Шимон С.І. Цивільне та торгове право зарубіжних країн: навч. посібник (Курс лекцій). Київ: КНЕУ, 2004. 220 с.

17. Юніна М.П. Уніфікація право- та дієздатності юридичних осіб у міжнародному приватному праві: автореф. дис. на здобуття наук. ступеня канд. юрид. наук: 12.00.03. Харків, 2011. $22 \mathrm{c}$.

Received to editorial office 29.05.2018

\section{Summary}

The article deals with the study of the role of personal law and nationality in determining the legal capacity and capacity of foreign legal entities in international private law. The author also describes the criteria for determining the nationality of foreign legal entities and the current trends in determining the nationality of legal entities.

Keywords: foreign legal entity, personal law, legal entity's nationality, civil capacity of legal entity. 